\title{
The Influence of Informal Learning in Promoting Entrepreneurial Capacity of Boutique Owners
}

\author{
T. J. Aruleba, O. T. Adeosun, and I. O. Adebowale
}

\section{ABSTRACT}

\begin{abstract}
Learning is a process that embodies all forms of activities which enables transgenerational transmitting of cultural values and prepares individuals for social living. Entrepreneurial capacity enables a firm to capitalize on a wide scope of fresh and alternative viewpoints that may challenge embedded assumptions and path-dependent cognitive schemes used by a firm. The specific objectives are to ascertain the impacts of informal learning in promoting entrepreneurial capacity; to determine the extent to which experimental learning is promoting entrepreneurial capacity and investigate the factors militating against the promotion of entrepreneurial capacity through informal learning. The data collected was analyzed using descriptive survey while Chi-square Statistics was used to test the stated hypothesis. The study adopts a simple random sampling technique to select 100 entrepreneurs who are into the sales of clothing materials or fabrics (ready-made clothesboutique) from the population (150). The study reveals that entrepreneurial capacity results in the creation of sources of capital or finance as part of the influence of informal learning. Goal orientation of boutique owners increases their entrepreneurial capacity. Motivation predicts the success of experimental learning in promoting entrepreneurial capacity. Also, it shows that individual(s) are likely to be at disadvantage in accessing informal learning opportunities, since everybody can't benefit equally by identifying opportunities. It recommended that business owners should expand their scope of informal learning to accommodate formal learning to make them entrepreneurship professionals and facilitators.
\end{abstract}

Keywords: Accidental learning, Entrepreneur's capacity, Experiential learning, SMEs, Unintentional learning, Unstructured learning.
Submitted : January 06, 2022

Published : February 26, 2022

ISSN: 2507-1076

DOI: $10.24018 /$ ejbmr.2022.7.1.1254

\section{T. J. Aruleba*}

Entrepreneurial Studies Department, Bamidele Olumilua University of Education, Science and Technology, Nigeria.

(e-mail: aruleba.tomisin@bouesti.edu.ng) O. T. Adeosun

Management Science Department, Bamidele Olumilua University of Education, Science and Technology, Nigeria.

(e-mail: adeosun.titi@bouesti.edu.ng)

Dr I. O. Adebowale

Management Science Department, Bamidele Olumilua University of

Education, Science and Technology, Nigeria.

(e-mail: adebowale.isreal@bouesti.edu.ng)

*Corresponding Author

\section{INTRODUCTION}

Learning is ubiquitous in each phase of human civilization with diverse nature in each age. Formal learning refers to the system through which individuals develops potentials and their maximization in achieving self-fulfillment (Agbionu et al, 2016; Ekwosi, 2012). It plays an important role in human development and forms an integral instrument deployed by a society in making humans productive and developing a behavioral pattern (Chipesha, 2020). Alternatively, informal learning possesses the ability to revolutionize the cultural, political and socio-economic growth of a nation (Berg, 2017). It is a learning process that commences with family and develops from daily activities, work, and social interaction society. As noted by (Evans et al., 2020; Fontes, 2020), it is often referred to as experimental or experiential learning due to its lack of structure in terms of learning objectives, time and support. Typically, it does not lead to certification and may either be intentional or unintentional. The contemporary and dynamic informal learning world has actively engaged entrepreneurs in social media platforms such as Twitter, Facebook, and Instagram. This has made it easier for them to connect with friends, made sales, gather digital experience and represent a priority in their daily life (Al-kadi, 2020).
Entrepreneurs solve the societal problem(s) by creating values. They represent an integral part of economic development and dynamism through the capacity of problemsolving and employment creation (Xiao \& Carrol, 2007). Entrepreneurs, according to Adebowale, (2009), apply strong mental effort, clear thinking, courage, confidence, and proactive actions in value creation. Recent dimensions to entrepreneurship have necessitated the need for informal learning for business management skills. However, this study focuses on unstructured learning because of its capability to increase entrepreneurial awareness, opportunities, and exploration. As noted by (Komarkova et al., 2015; Wei et al., 2019), entrepreneurial capacity is a firm's capacity to continuously exploit opportunities due to its access and capitalization on novel information thereby resulting in unprecedented and competitive performance. Due to entrepreneurial capacity, a firm becomes exposed to the diverse alternative perspective that represents the heterogeneity of its external environment (Nowak, 2014). In the context of this study, entrepreneurial capacity represents the ability of boutique owners to exploit new opportunities that result in improved quality service, customer satisfaction, customer loyalty and increased sales (Lv et al., 2011). 
The reality of the economic harshness in Nigeria has created entrepreneurs out of people. The majority of ventures has been engaged in diverse entrepreneurial activities and their capacity has increased their likelihood of exploring opportunities and increase their performance (Nowak, 2014). Also, there exist growing societal expectations on Small and Medium Scale Enterprises (SMEs) to fill the gap of the problem solving by reducing the unemployment rate and social crimes. It is however pertinent to note that this will be difficult to achieve without entrepreneurial capacity which is also influenced by informal learning (Põder et al., 2017). Likewise, boutique owners need the entrepreneurial capacity to flourish in their business. Informal learning has a widespread and long-standing history. Despite this, it has received miniature attention from researchers than its counterpart. Notably, there exist colossal pieces of literature on formal learning while there are sparing studies on informal learning. This seems to be, since unstructured learning is ambiguous to survey than structured learning (Amorim et al., 2020). On this note, this study seeks to fill this gap by investigating the influence of informal learning in promoting the entrepreneurial capacity of boutique owners. Specifically, the study seeks answers to the following research questions:

i. What are the impacts of informal learning in promoting entrepreneurial capacity?

ii. What is the extent to which experimental learning is promoting entrepreneurial capacity?

iii. What are the factors militating against the promotion of entrepreneurial capacity through informal learning?

\section{A. Hypothesis}

As submitted by Aruleba, (2019), hypotheses are postulated on an unexpected or unknown statement, which after testing will reveal whether or not, there is an association. The hypothesis is stated in null form and tested at 0.05 degree of freedom.

$\mathbf{H}_{01}$ : There is no significant relationship between informal learning and quality service delivery.

H1: There is significant relationship between informal learning and quality service delivery.

\section{LITERATURE REVIEW}

\section{B. Informal Learning and Entrepreneurial Capacity}

The philosophy of informal learning proposes that the world is full of potential educational opportunities and indeed, the greater part of human's education is acquired informally (Knezek et al., 2011). This study aligns with this philosophy, as the social interaction, social arrangement, and social engagement of human on daily basis outweighs the hours human spent in four wall classrooms. And for those who have passed this stage, they completely shift to the circle of situational learning which the study also referred to as accidental, unstructured, unintentional, and experiential learning. Thus, unstructured learning is crucial to promotion of entrepreneurial capacity in any business circle.

Informal learning is an unorganized and unsystematic view of education. It represents a spontaneous process that enables people to learn at a different pace (Njanike, 2019).The literature indicated a process that enables individual to learn at different pace, but it fails to mention if there are indices responsible for this e.g., socio-demographic characteristics and the extent to which individuals can learn at different pace. Notably, informal learning is void of rules and regulations and does not necessarily entail learning objectives usually covered by formal curricula(Harte, 2019), but rather, aims at the society at large with no imposition of obligation. The current study opined that informal learning is built on the strengths of morals, unwritten rules, and regulations. The study concludes that the blend of formal, informal, and nonformal learnings is central to successful building of entrepreneurial capacity in all spheres.

As posited by (Gomez et al., 2020; Kyrgidou et al., 2021; Light \& Dana, 2013), informal learning operates through conversation, exploration and enlargement of experience with a purpose of cultivating associations, relationships and communities that enables human to flourish. Likewise, Nowak (2014) views informal learning as a type of learning obtained through several life experiences such as individual skills which enable survival and sustainability. Although informal learning does not result in certifications and has no control over the activities performed, it supplements formal learning (Noy et al, 2016; Nowak, 2014). In reality, the study tows another part based on the issue of certification. An aspect to the informal learning, which is the apprenticeship requires certification, besides institutions of higher learning awards certificate not only in academic satisfaction, but as well as character.

Informal learning is quite diverse from formal learning and it includes several types of learning such as noncredit learning, work-based learning, service or civic learning, mentoring or coaching, and communities of practice (Noy et al, 2016). However, Boyer et al. (2014) asserted that informal learning might not benefit people at the same rate, it was further stressed that it has an increased lifelong benefit, which if adopted by entrepreneurs tends to increase their capacity of success. Based on the previous inputs of this study to the pieces of literature, it therefore concurs with this assertion. By extension, the study implores people from all spheres of life to encourage and utilize informal learning.

Entrepreneurial capacity is a dynamic construct that enables continuous access to opportunities (Oyolola \& Otonne, 2020). It is the ability to exploit opportunities in terms of innovation and competition (Nowak, 2014). It entails the skills to identify and explore new business opportunities and the ability to commence new ventures and expand existing ones. The ability to spot new opportunities and pursue it according to Harte (2019), stems from ambition and the desire for achievement, ability to take a risk, tolerance for ambiguity and ability to make decisions under uncertainties, self-efficacy, willingness to learn from experience and the ability to provide good leadership. The current study concludes that opportunities will continue to avail entrepreneurs that adopts and utilizes entrepreneurial capacity.

Entrepreneurial capacity plays a pivotal role in the case of SMEs (Njanike, 2019). It entails distinct elements such as passion, integrity, commitment, active learning and analysis, demonstration and practical, leadership and management. In addition, entrepreneurial capacity encompasses the framework of opening new paths, balancing business for commercial interest and purpose, and the integration of new 
resources (Afzal et al., 2017). The literature didn't note, the balancing variables needed to stimulate commercial interest and the extent to which old and new resources can be integrated. The opening up of a new path of action represents the first step an entrepreneur needs to seek to explore new business ideas and expand existing business. The capacity to balance business for commercial purposes and interest entails legitimizing the business and its commercial activities. In this situation, an entrepreneur needs the ability to conceive ideas that help to strike a balance. The current study further concurs and submitted that such ideas will lead to commercial purpose with the basement of entrepreneurial capacity. Lastly, the new resources integration ability of an entrepreneur depends largely on the entrepreneur's ability to network and the regional entrepreneurship opportunity available. Furthermore, (Gomez et al., 2020; Kyrgidou et al., 2021; Light \& Dana, 2013) are of the opinion that an entrepreneur will often seek entrepreneurial opportunities in a region such opportunities exist. This often strategically makes an entrepreneur capitalize on their networks and resources globally. In the quest of boutique owners to increase their entrepreneurial capacity, they are, however, faced with challenges such as inadequate fund, instability in governance and inadequate information generation. The current study opines that, these can be well catered for by the exploration of the abounding opportunities on the premises of the boutique owner's networks. All these can be combated with the aid of informal learning(Boyer et al., 2014; Latchem, 2014).

\section{Theoretical Framework: Innovative Theory of Entrepreneurship}

It's expedient to theoretically base constructs in an inquiry. This was propounded by Joseph Schumpeter in the $20^{\text {th }}$ century. He posits that entrepreneurs transform the stationary circular flow of the economy by introducing innovation thereby taking the economy to a new level of productivity. The theory stated that the economic development of a nation is dependent on the entrepreneurs' innovation. Innovation is viewed as the combination of the novel factor of production, new products and production processes, market expansion, novel management styles, and new sources of raw material supplies. Schumpeter sees an entrepreneur as an innovative man who does not possess ordinary managerial skills but consistently introduces new ideas (Akinyemi et al., 2015; Aruleba, 2019). The current study accepted that, the cultivated entrepreneurial capacity of the boutique owners will spur them to dive into sales of different product line combining degrees of managerial capabilities.

As stated by Bula, 2012; Mtshali \& Chinyamurindi, 2021; Petrella \& Richez-Battesti, 2014, the introduction of new products means, customers can access better and quality product than what is already in existence, and novel production processes will increase productivity and reduce the cost of production. The investigation noted that, due to the managerial capabilities and possession of entrepreneurial capacity, the fashion enthusiasts will have arrays of clothing to select and purchase.

According to Nowak (2014), entrepreneurs cannot be innovative without entrepreneurial capacity and informal learning plays a vital role in developing and influencing the capacity of an entrepreneur. Corroborating this, Bula (2012) stated that entrepreneurs increase in innovation once their capacity is expanded through accidental learning. The increment in the innovative capacity of entrepreneurs through informal learning increases their entrepreneurial capacity which helps in developing the economy. The current study wraps the theory adopted, that innovative boutique owners are functions of entrepreneurial capacity and unstructured learning.

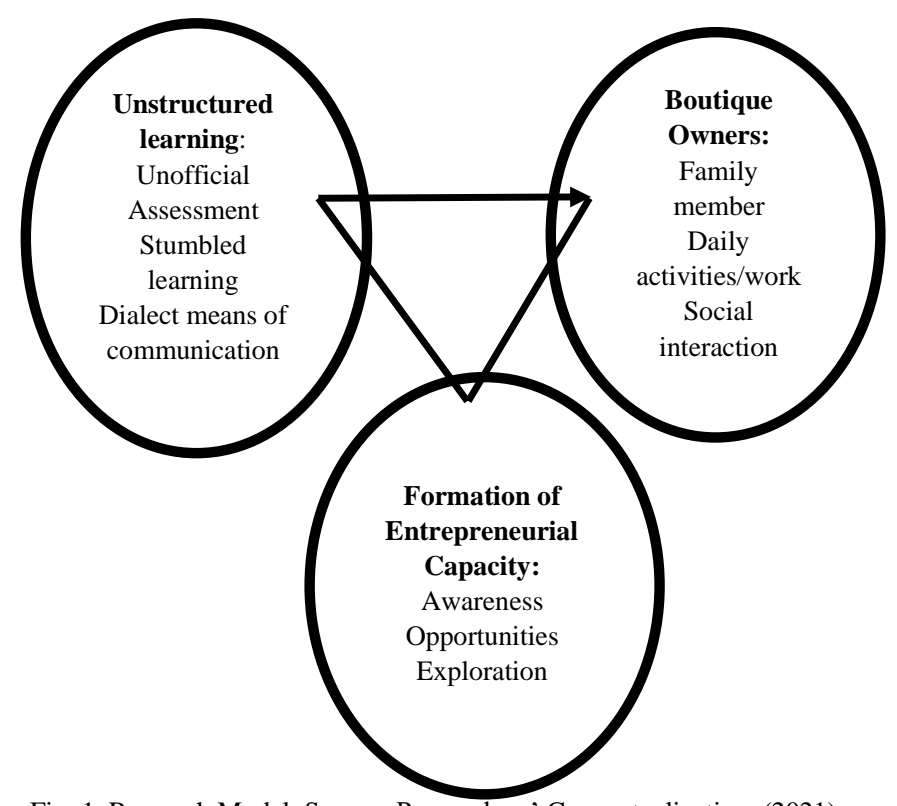

Fig. 1. Research Model. Source: Researchers' Conceptualization, (2021).

\section{RESEARCH SETTING AND METHODOLOGY}

The research design used was a descriptive survey (DS). It can answer the questions of what, where, when and, how. But it is inappropriate for the why questions. It systematically describes facts, qualities, attributes or characteristics of a given population (McCombes, 2020), events or constructs as factually as possible to answer the inquiry's question(s). The usage of a descriptive survey is to wholly or partially confirm existing authors' efforts in the same, similar or entirely different field, and to empirically add to the body of knowledge in such construct(s). It is numerical i.e., quantitative. DS describes the existing situations regarding the promotion of entrepreneurial capacity via informal learning amongst boutique owners.

This study was carried out in Ikere Local Government Area of Ekiti State. Ikere is a city in the Ekiti State of Nigeria with a total population of about 147,355 . The city is majorly known, in the olden days, for agriculture and mining, but with the advent of civilization and the harsh economic situation in Nigeria, entrepreneurship and entrepreneurial acts on a small and large scale has been on the increase. The popular entrepreneurial venture practiced among the youth (students, graduates) and housewives in the city is the sales of clothing materials or fabrics (ready-made clothes-boutique) and fashion accessories.

The population for the study comprises boutique owners within Local Government. Ikere city has a population of 150 boutique owners. A probability sampling technique known as 
simple random was adopted to select 100 boutique owners who are into the sales of clothing materials/fabrics (readymade clothes-boutique). The adopted technique gives an equal chance of selection to the entire population. It gives no room for bias or preferential treatment. Also, the randomization ascertains the instrument's validity. The data collected for the demographic characteristics of the entrepreneurs are analyzed using frequency count and valid percentage. While section B-D was analyzed using mean and standard deviation. While a non-parametric statistic called Chi-square was employed to test the variables in the research hypothetical statement. The test of Chi-square is used for categorical variables. It is the best suit for ratio one-one (1:1). The statistical package for social science (SPSS) version 25 was adopted as the statistical tool for the study. The study adopted a five-point Likert scale (Undecided, Disagree, Strongly Disagree, Agree and, Strongly Agree) with the following corresponding rating $0,1,2,3$ and, 4 respectively.

$$
\frac{1+2+3+4}{4}=2.5
$$

Therefore, the mean score is 2.5 .

Note:

i. A ten percent provision was made for unreturned instrument i.e., 10 extra making 110 distributed. In reality, the study affirms that there is no way research can achieve $100 \%$ collection rate, due to controllable and uncontrollable factors. Hence, there is need to make provision for such irrecoverable instrument. Since there is need to meet up with the calculated or adopted sample size.

ii. 0 for the undecided was excluded because the study regarded it as insignificant.

\section{RESULTS}

Table I below depicts the demographic characteristics of the respondents.

The highest $(61.0 \%)$ category of gender goes to the female, this didn't come as surprise, as some studies and observations had revealed that female is more involved in boutique businesses than their male counterpart. A greater part of the respondent $(56.7 \%)$ fell into the age category of 21-30 and directly followed by the 31-40 category. This indicates that more than half of the respondents are youth and active, as such, they are still in good shape to run the business for years effectively and efficiently based on the experiences they had gathered and the one to be gathered. Also, majorities (72.2\%) of the respondent are Christians, followed by the Islamic faithful $(27.8 \%)$ and three of the respondents declined their views. This shows that Christians domicile in this location than other religions. In addition, $(49.0 \%)$ of the respondents are singles, married accounted for $(46.0 \%)$ while only $(5.0 \%)$ are divorce. It indicates that they are less committed to other activities of life and thus have enough time to devote to their boutique business.

Educational Qualification-Bachelor of science which accounted for the largest percentage of the respondents belongs to $(69.4 \%)$ and followed serially by Msc (17.3\%), NCE $(9.2 \%)$ and No formal education $(4.2 \%)$. This denotes that the boutique owners are well-read, they will be able to apply their knowledge of academic with the demand of their business effectively, that will be in turn lead to the huge output. Likewise, Years of Experience- the biggest of the category (1-5) accounted for $50.0 \%$ i.e., half. The respondents that fall to the experience range of 16-20 (19.5\%) followed and others follow in this descending other $(17.1 \%)$ and $(13.4 \%)$. The revelation here is that the years of experience is something to rely and leverage on, in other to achieve the business goal(s).

TABLE I: DEMOGRAPHIC CHARACTERISTICS OF RESPONDENTS SOURCE: FIELD SURVEY, (2019)

\begin{tabular}{|c|c|c|}
\hline Variable & Frequency & Percentage \\
\hline Gender & romer & 300 \\
\hline Male & 39 & 39.0 \\
\hline Female & 61 & 61.0 \\
\hline Total & 100 & 100.0 \\
\hline \multicolumn{3}{|l|}{ Age } \\
\hline $21-30$ & 55 & 56.7 \\
\hline $31-40$ & 27 & 27.8 \\
\hline 41 and above & 15 & 15.5 \\
\hline No Response & 3 & - \\
\hline Total & 100 & 100.0 \\
\hline \multicolumn{3}{|l|}{ Religion } \\
\hline Christianity & 70 & 72.2 \\
\hline Islam & 27 & 27.8 \\
\hline No Response & 3 & - \\
\hline Total & 100 & 100.0 \\
\hline \multicolumn{3}{|l|}{ Marital Status } \\
\hline Married & 46 & 46.0 \\
\hline Single & 49 & 49.0 \\
\hline Divorced & 5 & 5.0 \\
\hline Total & 100 & 100.0 \\
\hline \multicolumn{3}{|l|}{ Educational Qualification } \\
\hline No Formal Education & 4 & 4.1 \\
\hline NCE & 9 & 9.2 \\
\hline BSC & 68 & 69.4 \\
\hline MSC & 17 & 17.3 \\
\hline No Response & 2 & - \\
\hline Total & 100 & 100.0 \\
\hline \multicolumn{3}{|l|}{ Years of Experience } \\
\hline $1-5$ & 41 & 50.0 \\
\hline $6-10$ & 14 & 17.1 \\
\hline $11-15$ & 11 & 13.4 \\
\hline $16-20$ & 16 & 19.5 \\
\hline No Response & 18 & - \\
\hline Total & 100 & 100.0 \\
\hline
\end{tabular}

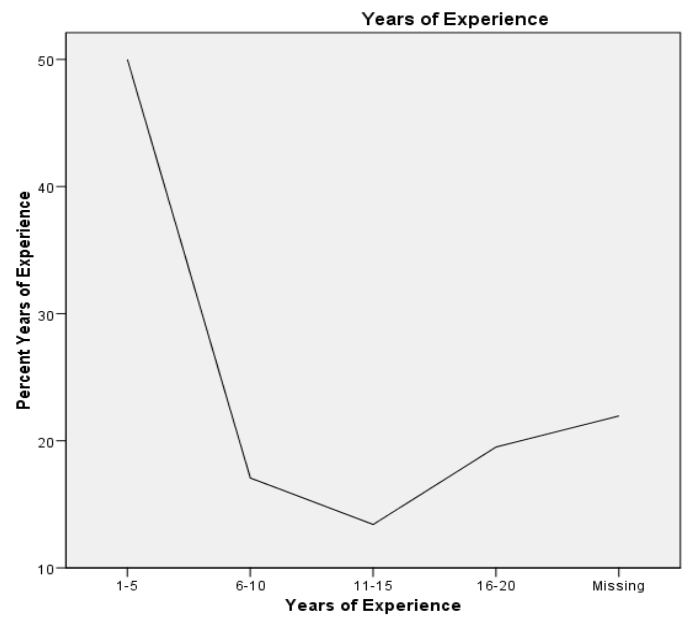

Fig. 2. Interpolation line depicting years of experience in running a boutique. Source: Field Survey, (2019).

Table II indicated that all the statements $(1,2,3,4,5,6,7$, 8 and 9) have mean values of $2.78,2.99,2.73,2.79,2.97$, $3.02,3.06,3.09$ and 2.86 respectively, the mean values are above the mean cut off point of 2.50 . All the statements are 
accepted since they are above the mean cut off point. This implies that informal learning/accidental learning in one way or the other, have impacted the promotion of entrepreneurial capacity. This finding is in accordance with the studies of (Montoro-Sánchez \& Díez-Vial, 2013), (Evans et al., 2020; Fontes, 2020) who found out that informal learning meaningfully promotes entrepreneurial capacity either as an individual or organization.

Individualize or collective entrepreneurial capacity facilitates the best of results for the factors of production. The maximum usage of the combination land, labour, capital and enterprise has been scaled by entrepreneurial capacity. Hence, labour has been able to effectively deliver, the land resource has been used judiciously without wastage, money has been expended wisely with greater returns and, the entrepreneur has been able to harness other resources for better results, due to the possessed individualize entrepreneurial capacity by the business owners.

The knowledge gained from the training of entrepreneurial capacity has led to multiple creations of business. This reflects the importance of entrepreneurial capacity to individuals. Thus, entrepreneurial capacity is a mechanism that aid the creation of new ventures.

Informal learning has become a bridging gap between formal and non-formal learning in the process of acquiring entrepreneurial capacity. Accidental learning has proved that all forms of learning are crucial to the acquisition and development of entrepreneurial capacity by individuals and groups of individuals. In the broader perspective of the economy, experimental learning is capable of facilitating and revolutionizing the socio-economic. Hence, various authorities in the public and private sector should come up with a policy on entrepreneurial capacity so that the collective efforts will bless the company's economic growth and the nation's economic prowess.

\begin{tabular}{|c|c|c|c|c|}
\hline $\mathrm{S} / \mathrm{N}$ & Statements Mean & & Std. dev & Remark \\
\hline 1 & Entrepreneurial capacity enhances combination of factors of production. & 2.78 & 0.86 & Accepted \\
\hline 2 & Entrepreneurial capacity helps entrepreneurs to create new business. & 2.99 & 0.75 & Accepted \\
\hline 3 & $\begin{array}{l}\text { Informal learning is capable of maintaining closer relationship between formal and non-formal } \\
\text { learning in enhancing entrepreneurial capacity. }\end{array}$ & 2.73 & 0.96 & Accepted \\
\hline 4 & $\begin{array}{l}\text { The informal learning/experimental learning have the potential of revolutionizing socio- } \\
\text { economic, and entrepreneurial capacity of individuals. }\end{array}$ & 2.79 & 0.95 & Accepted \\
\hline 5 & Workers capacity as a self-efficacy enhances entrepreneurial training. & 2.97 & 0.78 & Accepted \\
\hline 6 & Entrepreneurial activities help individual to develop entrepreneurial capacity. & 3.02 & 0.73 & Accepted \\
\hline 7 & Individual cognitive ability as a skill, influences training output positively. & 3.06 & 0.77 & Accepted \\
\hline 8 & The tendency to learn, deposited in individual cravens you to learn more. & 3.09 & 0.61 & Accepted \\
\hline 9 & $\begin{array}{l}\text { Experiences gained in promoting entrepreneurial capacity through unstructured learning } \\
\text { determines the long-run size of the firm. }\end{array}$ & 2.86 & 1.17 & Accepted \\
\hline \multicolumn{5}{|c|}{ Source: Field Survey, (2019). } \\
\hline \multicolumn{5}{|c|}{ TABLE III: THE EXTENT TO WHICH EXPERIMENTAL LEARNING PROMOTES ENTREPRENEURIAL CAPACITY } \\
\hline $\mathrm{S} / \mathrm{N}$ & Statement & Mean & Std. DV & Remarks \\
\hline 10 & To what extent does entrepreneurial capacity result in the creation of sources of capital/Finance? & 2.72 & 0.83 & Accepted \\
\hline 11 & $\begin{array}{l}\text { To what extent, does heterogeneous firm's acquires more competitive capabilities than } \\
\text { homogenous firm? }\end{array}$ & 2.67 & 0.94 & Accepted \\
\hline 12 & $\begin{array}{l}\text { To what extent does, entrepreneurial capacity lead to more diversity in the content of structural } \\
\text { social capital of a firm? }\end{array}$ & 2.79 & 0.86 & Accepted \\
\hline 13 & $\begin{array}{l}\text { To what extent does, individualize cognitive ability affects training that could enhance } \\
\text { entrepreneurial capacity? }\end{array}$ & 2.86 & 0.73 & Accepted \\
\hline 14 & $\begin{array}{l}\text { To what extent does, goal orientation of boutique owners increases his/her entrepreneurial } \\
\text { capacity? }\end{array}$ & 2.79 & 0.86 & Accepted \\
\hline 15 & $\begin{array}{l}\text { To what extent does, motivation predicts the success of experimental learning in promoting } \\
\text { entrepreneurial capacity? }\end{array}$ & 2.82 & 0.73 & Accepted \\
\hline 16 & To what extent does, individual entrepreneurial capacity helps to transform uncertainty into risk? & 2.86 & 0.94 & Accepted \\
\hline 17 & To what extent does, individual entrepreneurial capacity helps to transform uncertainty into risk? & 2.86 & 0.94 & Accepted \\
\hline
\end{tabular}

The result in Table III revealed that all the items (10, 11, $12,13,14,15,16$ and 17) have corresponding mean values of $2.72,2.67,2.79,2.86,2.79,2.82$ which are greater than the calculated mean scores of 2.50 . Therefore, the study accepts all the values $2.72,2.67,2.79,2.86,2.79,2.82$ and 2.86 for the statements, and it is concluded that experimental learning promotes entrepreneurial activities to a greater extent. This is in agreement with the work of (Boyer et al., 2014).

Availability of entrepreneurial capacity has led to the creation of finances to the ventures, this would assist the businesses to have a broader capital base to finance operations. Also, this will create an avenue for expansion either in the same line of business or similar business. Acquisition and possession of entrepreneurial capacity have to a high extent led to diversification in the business operations. The direct and indirect diversifications have increased their chain of business and increase business prowess. Also, the popularity and good reputation that accompanies the diversification will give the boutique businesses the competitive edge in the sub-sector.

The individual cognitive ability has enabled the trainees to build high entrepreneurial capacity. This is a way of personally developing abilities. It has assisted the boutique owners to cope effectively during and after the training. The possessed entrepreneurial capacity has to a high extend transform the risk uncertainty that is attached to the boutique business. This is an avenue to boost the resilience state of the boutique business. The acquired entrepreneurial capacity has spurred the boutique owners to mitigate, avoid, mitigate, and transfer risks associated with their business. The aftermath effect of this is that the boutique business becomes more resilient in the face of certain and uncertain risks in the contemporary economy. 
TABLE IV: FACTORS MILITATING AGAINST THE PROMOTION OF ENTREPRENEURIAL CAPACITY THROUGH INFORMAL LEARNING

\begin{tabular}{clcc}
\hline S/N & \multicolumn{1}{c}{ S/N Statement } & $\begin{array}{c}\text { Mean Std. } \\
\text { Dev }\end{array}$ & Remark \\
\hline \multirow{3}{*}{18} & $\begin{array}{l}\text { Individuals are likely to be at } \\
\text { disadvantage in accessig informal } \\
\text { learning opportunities since } \\
\text { everybody can't benefit equally. } \\
\text { Providing access to training } \\
\text { courses does not always lead to } \\
\text { the development of } \\
\text { entrepreneurial capacity, which } \\
\text { might lead to high standards of }\end{array}$ & Rejected \\
living. & Accepted & \\
\hline Source: Field Survey, (2019). & & \\
\end{tabular}

Source: Field Survey, (2019).

The result in Table IV reveals that learning variation and lack of access to training courses are negatives impeding the promotion of entrepreneurial capacity via situational learning. Item 17 that has a mean value of 2.12 will be rejected because it's less than the mean score of 2.5. Item 18 which has 2.51 as mean value will be accepted because it's greater than the calculated mean score of 2.5. Therefore, it was concluded that learning variation does not impede the promotion of entrepreneurial capacity. Frequent access to training materials doesn't lead to the promotion and development of entrepreneurial capacity. As such there might be underlying factors responsible for frequent stimulation of entrepreneurial capacity. By implications, individuals can learn at their own pace and benefit, as such it will enhance their entrepreneurial capacities. This would as well facilitate the needed growth in such an entrepreneurial endeavour. Mechanisms to promote entrepreneurial capacities might be ineffective since the constancy of access to training materials doesn't guarantee entrepreneurial capacities. This revelation agrees with the empirical study of (Rezai et al, 2011) who find out that learners benefit from situational learning at different times and places. It also negates the findings of(Boyer et al., 2014) who stipulated that access to training materials guarantees promotion and development of entrepreneurial capacities of learners or apprentices.

TABLE V: CHI-SQUARE TEST OF ASSOCIATION BETWEEN INFORMAL LEARNING AND QUALITY SERVICE DELIVERY

\begin{tabular}{|c|c|c|c|}
\hline & \multicolumn{3}{|c|}{ Chi-Square Tests } \\
\hline & Value & $\overline{\mathrm{Df}}$ & Asymp. Sig. (2-sided) \\
\hline Pearson Chi-Square & $32.442^{\mathrm{a}}$ & 16 & 0.009 \\
\hline Likelihood Ratio & 22.019 & 16 & 0.143 \\
\hline $\begin{array}{l}\text { Linear-by-Linear } \\
\text { Association }\end{array}$ & 2.068 & 1 & 0.150 \\
\hline $\mathrm{N}$ of Valid Cases & 100 & & \\
\hline
\end{tabular}

Table V shows the Chi-Square result of significant association between informal learning and quality service delivery. Since the p-value (0.009) is less than the chosen level of significance $(\alpha=0.05)$, therefore the null hypothesis is rejected and then state that there is a significant relationship between informal learning and quality of service delivery. The implication of this is that the capacity of the informal learning has triggered quality customer service and as well help to increase customer base and profit.

\section{CONCLUSIONS AND RECOMMENDATION}

All the statements were accepted, which shows that informal learning promotes entrepreneurial capacity. It is of a high extent that, entrepreneurial capacity results in the creation of sources of capital or finance. Goal orientation of boutique owners increases their entrepreneurial capacity. Motivation predicts the success of experimental learning in promoting the entrepreneurial capacity and individual entrepreneurial capacity helps to transform uncertainty to risk. Individuals are likely to be at disadvantage in accessing informal learning opportunities since everybody can't benefit equally by identifying opportunities. Informal learning help in increasing the knowledge base in the enhancement of entrepreneurial capacity by identifying opportunities and equipping boutique owners with the knowledge of technology. It is also found that boutique owners should make provision for informal learning to promote their enterprise. The study, therefore, recommends that business owners should expand their scope of informal learning to accommodate formal learning to make them entrepreneurship professionals and facilitators.

\section{PRACTICAL AND MANAGERIAL SignificANCE}

The implications of the study's findings span through the practical and managerial relevance on promotion of entrepreneurial capacity of boutique owners on the premises of situational learning. The study has scientifically assessed the state of affairs on the boutique owners, which has given no space for assumptions, guess and predictions. Furthermore, the managers, business owners and apprentice will empirically be aware of the values in possession and adaptation of entrepreneurial capacity on daily basis, plus the variance in informal leaning of individuals.

\section{CONFLICT OF INTEREST}

There is no conflict of interest.

\section{REFERENCES}

Adebowale, I. O. (2009). The place of entrepreneurship in Nigeria's economy development. Journal of Research in Vocational and Technical Education, 6(1), 164-175.

Afzal, M. N. I., Mansur, K. B. H. M., \& Sulong, R. S. (2017). An empirical investigation of ttriplehelix and national innovation system dynamics in ASEAN-5 economies. Asian Journal of Innovation and Policy, 6(3), 313-331. DOI: http//dx.doi.org/https://doi.org/10.7545/ajip.2017.6.3.313.

Agbionu, E., Joseph, C., \& Ifeyinwa, N. (2016). Need-Oriented Curriculum in Our Education System: A Strategy for Capacity Building in Nigeria. Arts and Social Sciences Journal, 7(4), 2. https://doi.org/10.4172/2151-6200.1000209.

Akinyemi, B., Okoye, A. E., \& Izedonmi, P. F. (2015). History and development of accounting in perspective. International Journal of Sustainable Development Research, 1(2), 14-15. https://doi.org/10.11648/j.ijsdr.20150102.11.

Al-kadi, A. M. T. (2020). Enhancements and Limitations to ICT-Based Informal Language Learning: Emerging Research and Opportunities (Ahmed, Rashad, Al-kadi, Abdu, Hagar, \& Trenton (eds.)). IGI Global. https://books.google.com.ng/books?id=jkHADwAAQBAJ.

Amorim, J. P., Crespo, N., \& Teixeira, L. (2020). Infection, Participation and Informality in Higher Arts Education: The Case of the School 
of Arts (Porto). European Journal of Cultural Management \& Policy, 10(2), 52.

Aruleba, T. J. (2019). The Basic financial accounting knowledge: A panacea for successful entrepreneurship study, among postgraduate students in the university of Ibadan. American Journal of Creative Education, 2(4), 173,174, 175, 176, 179. https://doi.org/10.20448/815.24.173.186.

Berg, G. H. Van der. (2017). A Framework to Integrate the Formal Learning with the Informal Workplace Learning of Statisticians in a Developmental State [University of South Africa]. https://core.ac.uk/download/pdf/83637598.pdf.

Boyer, S. L., Edmondson, D. R., Artis, A. B., \& Fleming, D. (2014). Selfdirected learning: A tool for lifelong learning. Journal of Marketing Education, 36(1) https://doi.org/10.1177/027347538000200201.

Bula, H. (2012). Evolution and theories of entrepreneurship: A critical review on the Kenyan perspective. International Journal of Business and Commerce, 1(11), 84. www.ijbcnet.com.

Chipesha, G. (2020). The impact of formal education on the development of an individual. A case study of Chawama township. Cavendish University.

Evans, J. R., Karlsven, M., \& Perry, S. B. (2020). Informal learning. In R. Kimmons \& S. Caskurlu (Eds.), The students' guide to learning design and research (Vol. 2, Issue 6). EdTech Books. https://doi.org/10.1002/wcs.143.

Fontes, J. (2020). Informal and incidental education. formal, non-formal, informal and incidental education. https://coletividad.org/formalnon-formal-informal-and-incidental-education/

Gomez, C., Perera, B., Wesinger, J., \& Tobey, D. (2020). Immigrant entrepreneurs and community social capital: an exploration of motivations and agency. Journal of Small Business and Enterprise Development, $\quad 27(4), \quad 581$. http://jurnal.globalhealthsciencegroup.com/index.php/JPPP/articl e/download/83/65\%0Ahttp://www.embase.com/search/results?su baction=viewrecord $\&$ from=export $\&$ id=L603546864\% $5 \mathrm{Cnhttp} / /$ dx.doi.org/10.1155/2015/420723\%0Ahttp://link.springer.com/10 .1007/978-3-319-76887-.

Harte, D. (2019). Multifractals theory and applications (First). Routledge Taylor and Francis Group.

Komarkova, I., Gagliardi, D., Conrads, J., \& Collado, A. (2015). Entrepreneurship competence: an overview of existing concepts, policies and initiatives. Joint Research Centre Work, 11, 55 https://doi.org/10.2791/067979.

Kyrgidou, L., Mylonas, N., Petridou, E., \& Vacharoglou, E. (2021). Entrepreneurs' competencies and networking as determinants of women-owned ventures success in post-economic crisis era in Greece. Journal of Research in Marketing and Entrepreneurship, ahead-of-print(ahead-of-print). https://doi.org/10.1108/JRME08-2020-0105.

Latchem, C. (2014). Informal learning and non-formal education for development. Journal of Learning for Development, 1(1).

Light, I., \& Dana, L. P. (2013). Boundaries of social capital in entrepreneurship. entrepreneurship: Theory and Practice, 37(3), 605. https://doi.org/10.1111/etap.12016.

Lv, R. W., Lai, C., \& Liu, J. (2011). Entrepreneurial capability scale and new venture performance: The moderating role of entrepreneurship education.

McCombes, S. (2020). Descriptive research. Research Design. https://doi.org/10.4135/9781412952644.n132.

Montoro-Sánchez, Á., \& Díez-Vial, I. (2013). Entrepreneurial Capacity and Social. Complutense University of Madrid.

Mtshali, S. S., \& Chinyamurindi, W. T. (2021). Determinants of small business performance in a selected region in South Africa: The role of entrepreneurial orientation and competitive advantage. Journal of Contemporary Management, 18(1), 5.

Njanike, K. (2019). The factors influencing SMEs growth in Africa: A case of SMEs in Zimbabwe. In N. Edomah (Ed.), Regional Development in Africa (p. 13). Intech. https://doi.org/DOI: 10.5772/intechopen.87192.

Nowak, R. (2014). Entrepreneurial capacity and culture of innovation in the context of opportunity exploitation. University of Illinois at Urbana-Champaign.

Noy, M. Van, James, H., \& Bedley, C. (2016). Reconceptualizing learning: A review of the literature on informal learning. https://www.google.com/url?sa=t\&rct=j\&q=\&esrc=s\&source=w eb\&cd=1\&cad=rja\&uact=8\&ved=2ahUKEwij7YDj8bTeAhVBP BoKHdJFCJUQFjAAegQIBxAC\&url=https\%253A\%252F\%252 Fsmlr.rutgers.edu $\% 252$ Fsites $\% 252$ Fdefault $\% 252$ Ffiles $\% 252$ Fdo cuments\%252FInformal\%252520Learning\%252520Lit\%252520 Review\%252520Final\%25.
Oyolola, F., \& Otonne, A. (2020). Entrepreneurship, capacity development and youth employment generation: A study of selected sub-saharan Africa Countries. Munich Personal RePEc Archive, 99156, https://ideas.repec.org/p/pra/mprapa/99156.html.

Petrella, F., \& Richez-Battesti, N. (2014). Social entrepreneur, social entrepreneurship and social enterprise: semantics and controversies. Journal of Innovation Economics \& Management, 14(2), 150. https://doi.org/10.3917/jie.014.0143.

Põder, A., Kallaste, M., Raudsaar, M., \& Venesaar, U. (2017). Evaluation of entrepreneurial capacity of universities - A case of Estonia. 8th ICEEPSY 2017 The International Conference on Education and Educational Psychology, October, 2-4. https://doi.org/10.15405/epsbs.2017.10.92.

Rezai, G., Mohamed, Z., \& Shamsudin, M. N. (2011). Informal education and developing entrepreneurial skills among farmers in Malaysia. International Journal of Social, Behavioral, Educational, Economic, Business and Industrial Engineering, 5(7), 906-907.

Wei, X., Liu, X., \& Sha, J. (2019). How does the entrepreneurship education influence the students' innovation? Testing on the multiple mediation model. Frontiers in Psychology, 10(JULY), 2. https://doi.org/10.3389/fpsyg.2019.01557.

Xiao, L., \& Carrol, J. M. (2007). Fostering an informal learning community of computer technologies at school. Journal Behaviour \& Information Technology, 26(1), 24-25. https://dl.acm.org/citation.cfm?id=1392889. 